\title{
Immunosuppressive therapy in allograft transplantation: from novel insights and strategies to tolerance and challenges
}

\author{
AMMAR EBRAHIMI ${ }^{1}$, SEYED AHMAD HOSSEINI ${ }^{2}$, FAKHER RAHIM ${ }^{3}$
}

${ }^{1}$ Department of Medical Biotechnology, School of Advanced Medical Technology, Tehran University of Medical Sciences, Tehran, Iran ${ }^{2}$ Nutrition and Metabolic Disease Research Center, Ahvaz Jundishapur University of Medical Sciences, Ahvaz, Iran ${ }^{3}$ Health Research Institute, Hearing Research Center, Ahvaz Jundishapur University of Medical Sciences, Ahvaz, Iran

\begin{abstract}
Immunosuppression therapy is the key to successful post-transplantation outcomes. The need for ideal immunosuppression became durable maintenance of long-term graft survival. In spite of current immunosuppressive therapy regimens advances, surgical procedures, and preservation methods, organ transplantation is associated with a long-term poor survival and significant mortality. This has led to an increased interest to optimize outcomes while minimizing associated toxicity by using alternative methods for maintenance immunosuppression, organ rejection treatment, and monitoring of immunosuppression. T regulatory (Treg) cells, which have immunosuppressive functions and cytokine profiles, have been studied during the last decades. Treg cells are able to inhibit the development of allergen-specific cell responses and consequently play a key role in a healthy immune response to allergens. Mature dendritic cells (DCs) play a crucial role in the differentiation of Tregs, which are known to regulate allergic inflammatory responses. Advance in long-standing allograft outcomes may depend on new drugs with novel mechanisms of action with minimal toxicity. Newer treatment techniques have been developed, including using novel stem cell-based therapies such as mesenchymal stem cells, phagosomes and exosomes. Immunoisolation techniques and salvage therapies, including photopheresis and total lymphoid irradiation have emerged as alternative therapeutic choices. The present review evaluates the recent clinical advances in immunosuppressive therapies for organ transplantation.
\end{abstract}

Key words: immunosuppression, transplantation, immunoisolation, immune rejection, mesenchymal stem cells, exosomes.

(Centr Eur J Immunol 2014; 39 (3): 400-409)

\section{Introduction}

Immunosuppression therapy is the key to successful post-transplantation outcomes. The need for ideal immunosuppression became durable maintenance of long-term graft survival. Targeting multiple immune pathways with the hope of decreasing both acute and chronic allograft rejection in the field of solid organ transplantation has evolved during the past two decades. Though the medication used at various transplant centers has some differences, current approaches to immunosuppressive therapy in general are similar. Basic maintenance immunosuppressive regimens usually involve three diverse classes, including calcineurin inhibitors, antiproliferative agents, and corticosteroids. Although long-term outcomes after transplantation have improved with the medication and surgical advances, the rate of allograft rejection remains high. This has led to an increased interest in innovative strategies maintaining adequate immunosuppression and declining graft rejection. Novel treatment approaches have been developed including the use of stem cell-based therapies, phagosomes and exosomes. Besides, alternative therapeutic choices have been introduced by merging immunoisolation techniques with salvage therapies. In this review we try to give an insight into recent clinical advances of immunosuppressive therapies for allograft transplantation.

\section{Dendritic cells}

Dendritic cells (DCs) are probably the most professional antigen presenting cells (APC) of the mammalian immune system. Dendritic cells react through cell-cell contact or secretion of cytokines towards antigens, and play an important role in regulating the balance between the immune response and tolerance $[1,2]$. The most recent studies using DCs showed these cells as a promise or po-

Correspondence: Fakher Rahim, PhD, Health Research Institute, Hearing Research Center, Ahvaz Jundishapur University of Medical Sciences, Ahvaz, Iran, tel./fax +986113367562, e-mail: Bioinfo2003@gmail.com 
tential therapies in the field of cancers and other diseases. Dendritic cells prevent autoimmunity through two ways, consisting of induction of apoptosis in autoreactive $\mathrm{T}$ cells and by induction of anergy, deletion, or tolerance through cooperation with regulatory $\mathrm{T}$ cells (Treg) in the periphery. These cells are divided into the $\mathrm{cDC}$ and $\mathrm{pDC}$ types according to the function and surface markers $[1,3]$. The pDC type has the ability to detect the self and microbial DNA, and is recognized with overexpression of CD123 and interferon $\alpha$ (IFN- $\alpha$ ), which plays an important role in innate immunity [4], while under inflammatory conditions, and following Toll-like receptor (TLR) ligation and Ag uptake, cDC migrate to T cell areas of secondary lymphoid tissue to initiate adaptive immunity. Dendritic cells play a crucial role in the central and peripheral tolerance [5]. Central tolerance occurs in the thymus, in which thymoid DCs present self-antigens to the developing T cells, subsequently those $\mathrm{T}$ cells that show auto-reactivity above a certain threshold are eliminated. In the peripheral tolerance DCs fail to stimulate T cells sufficiently because of costimulatory factors and low expression of MHC molecules [6]. Furthermore, the absence of an appropriate antigen with expressing indoleamine 2,3-dioxygenase (IDO) by $\mathrm{DC}$, prevent the proliferation of $\mathrm{T}$ cells and will eventually eliminate them [5]. Besides, DCs induce Treg ability to maintain the tolerance mode [7].

To maintain the graft and reduce the use of immunosuppressive drugs, tolerogenic DCs of donor or host have been replicated and used in vitro. These methods used to prevent $\mathrm{T}$ cell effects of immune reactions of host-versusgraft or graft-versus-host. Dendritic cells derived from the recipient organs pulse with the donor antigen cell such as allopeptides and used to reduce response against the donor $\mathrm{T}$ cell and to create tolerance.

Intrathymic inoculation of BM-derived $\mathrm{mDC}$ pulsed with a donor allopeptide one week prior to transplantation induces tolerance in heart transplantation and pancreatic islet in rat model $[8,9]$. This method is suitable for children's heart surgery, because the young thymus is available during surgery. In one study it was shown that repetitive $(2 x)$ intravenous administration of BM-derived $\mathrm{mDC}$, pulsed with cell-free lysate from donor splenocytes caused a significant survival among $40 \%$ of fully MHC-mismatched cardiac allografts in mice [10]. In a study, an IV injection of donor's iDC seven days before transplantation triggered a significant survival of the heart graft (vascularized) and pancreatic islet (non-vascularized) in the rat [11, 12]. In another study, an injection of pDC with CD154 antibodies significantly prolonged the survival of the heart graft in the mouse [13].

Given the above fact, DCs are needed to replicate a few days before transplantation, which is applicable to live-donor renal and liver transplantation, but not to organ transplantation from deceased donors. It is also shown that when the donor-DCs are injected to transplant mice, there is a possibility of their elimination by NK cells as shown in mice [14].

\section{The regulatory $\mathbf{T}$ cells}

The regulatory $\mathrm{T}$ cell (Treg) is a component of the immune system that plays a role in maintaining immune homeostasis and immunosuppressive response. There are generally two types of Tregs, including natural Tregs (nTregs) that are derived from the thymus. Another type is iTreg, which develops outside the thymus under the presence of antigen and tolerogenic condition. The iTreg cells are divided into two categories, containing secreting transforming growth factor $\beta$ (TGF- $\beta$ ) (Th3 cells) and interleukin (IL)-10 (Tr1 cells) [15]. The nTreg constitutively express Foxp3 and CD25, thus a high and low expression of CD25 and CD127 is used to differentiate them from effector $\mathrm{T}$ cell used, respectively. The regulatory $\mathrm{T}$ cells undermine the operation of present antigens through direct action on DCs. These cells inhibit maturation of DCs via consuming the extracellular ATP synthesis and IL-2, and secretion of IL-10 and TGF- $\beta$. Treg cells also can kill conventional T cells (Tcons) using perforin and granzyme. Studies showed that nTreg plays an important role in protecting self-tolerance and preventing autoimmunity, while in vivo and in vitro activated iTreg plays a more important role in maintaining the graft and inducing tolerance during organ transplantation. Thus it seems that the main role of nTreg is tolerance to self-antigens, whereas iTreg is more responsible for tolerance to foreign antigens. Recent studies considering the application of regulatory $\mathrm{T}$ cells in transplantation are summarized in Table 1 .

\section{Mesenchymal stem cells}

Mesenchymal stem cells (MSCs) are of stromal origin and have been isolated from hair follicles, teeth, bone marrow, lungs, and adipose tissue [29]. Several studies have shown that MSCs have the potential to differentiate into endoderm and bone cells [30]. However, apart from this, MSCs also have great capacity to modulate the immune system through influencing T and B cells. Besides, MSCs influence T cell proliferation via cell-to-cell contact (programmed cell death-1 pathway) or factors such as TGF- $\alpha 1$ (transforming growth factor $\alpha 1$ ), IDO (indoleamine 2,3-dioxygenase), HO-1 (heme oxygenase-1), HGF (hepatocyte growth factor) and PGE2 (prostaglandin E2) [31-34]. Mesenchymal stem cells also decrease the proliferation of $\mathrm{B}$ cells via PD-1 and PD-L1 pathways and partly by using soluble factors in the blood [35]. Furthermore, MSCs reduce expression of MHCs and CD86, CD83 and CD40 molecules (Fig. 1).

Mesenchymal stem cells inhibit the maturation of myeloid-DCs derived from monocytes, and ultimately help to confront with antigen presenting cells (APCs) [36-39]. In 
Table 1. Recent studies using DCs in the various fields of transplantation

\begin{tabular}{|c|c|c|c|c|}
\hline $\begin{array}{l}\text { Author, } \\
\text { year }\end{array}$ & Host & Graft & Method & Findings \\
\hline $\begin{array}{l}\text { Sagoo et al., } \\
2013[16]\end{array}$ & $\begin{array}{l}\text { NOD/scid/IL- } \\
2 \mathrm{R} \gamma-/- \text { mice }\end{array}$ & skin graft & $\begin{array}{l}\text { alloantigen- } \\
\text { specific Tregs }\end{array}$ & significantly improved protection of human skin allografts \\
\hline $\begin{array}{l}\text { Wu et al., } \\
2013[17]\end{array}$ & $\begin{array}{l}\text { immunodeficient } \\
\text { BALB/c.rag2-/-. } \\
\text { c } \gamma-/- \text { mice }\end{array}$ & $\begin{array}{l}\text { islet } \\
\text { allograft }\end{array}$ & $\begin{array}{l}\text { ex vivo expanded } \\
\mathrm{CD} 25^{\text {high }} \mathrm{CD} 4^{+} \\
\text {human Treg }\end{array}$ & $\begin{array}{l}\text { co-transfer of Treg prolonged islet allograft survival and suppression } \\
\text { of proliferation and interferon- } \gamma \text { production by T cells }\end{array}$ \\
\hline $\begin{array}{l}\text { Issa et al., } \\
2013[18]\end{array}$ & $\begin{array}{l}\text { humanized } \\
\text { mouse model }\end{array}$ & $\begin{array}{c}\text { skin } \\
\text { allografts }\end{array}$ & $\begin{array}{l}\text { ex vivo expanded } \\
\text { human Treg }\end{array}$ & $\begin{array}{l}\text { stable long-term transplant survival along with a reduction in the } \\
\text { CD8+ human cellular graft infiltrate }\end{array}$ \\
\hline $\begin{array}{c}\text { Takasato } \\
\text { et al., } 2013 \\
{[19]}\end{array}$ & C57BL/6 mice & $\begin{array}{l}\text { cardiac } \\
\text { allograft }\end{array}$ & $\begin{array}{l}\text { ex vivo expanded } \\
\text { antigen-specific } \\
\text { iTreg }\end{array}$ & $\begin{array}{l}\text { iTregs induced via the indirect pathway had the greatest ability to } \\
\text { prolong graft survival and suppress angiitis. iTregs generated ex vivo } \\
\text { also induced long-term engraftment without using MHC peptides }\end{array}$ \\
\hline $\begin{array}{l}\text { Wolf } \text { et al., } \\
2012[20]\end{array}$ & $\begin{array}{l}\mathrm{C} 57 \mathrm{BL} / 6(\mathrm{H} 2 \mathrm{~b}) \\
\text { mice }\end{array}$ & $\begin{array}{l}\text { umbilical } \\
\text { cord blood } \\
\text { transplant }\end{array}$ & $\begin{array}{l}\text { Tregs expanded } \\
\text { in vivo by } \\
\text { TNFRSF25 }\end{array}$ & $\begin{array}{l}\text { significant prolongation of median graft survival from } 8 \text { days to } 17 \\
\text { days. Treated animals showed increased accumulation of Foxp3+Tregs } \\
\text { within the graft and decreased infiltration of inflammatory cells }\end{array}$ \\
\hline $\begin{array}{l}\text { Guo et al., } \\
2012[21]\end{array}$ & $\begin{array}{l}\mathrm{BALB} / \mathrm{c}(\mathrm{H}-2 \mathrm{~d}) \\
\text { mice }\end{array}$ & $\begin{array}{l}\text { corneal } \\
\text { allograft }\end{array}$ & $\begin{array}{l}\text { in vitro expanded } \\
\text { CD } 4^{+} \mathrm{CD} 25^{\text {high }} \\
\text { Foxp3 } 3^{+} \text {Treg }\end{array}$ & prevented fully MHC-mismatched corneal allograft rejection \\
\hline $\begin{array}{l}\text { Yi et al., } \\
2012[22]\end{array}$ & $\begin{array}{l}\text { NOD-SCID } \\
\text { IL2ry-/- mice }\end{array}$ & $\begin{array}{c}\text { islet } \\
\text { xenograft }\end{array}$ & $\begin{array}{l}\text { in vitro expanded } \\
\text { autologous Treg } \\
\text { in the absence } \\
\text { or presence of } \\
\text { (IL-10) }\end{array}$ & $\begin{array}{l}\text { Treg prevented islet xenograft by inhibiting graft infiltration of effector } \\
\text { cells and their function }\end{array}$ \\
\hline $\begin{array}{l}\text { Nadig et al., } \\
2011[23]\end{array}$ & 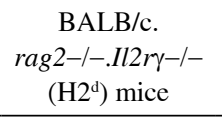 & $\begin{array}{c}\text { Aortic } \\
\text { xenograft }\end{array}$ & $\begin{array}{l}\mathrm{CD} 25^{\text {highCD}} 4^{+} \\
\text {and } \mathrm{CD} 127^{\mathrm{lo}} \mathrm{CD} 4^{+} \\
\text {expanded Treg }\end{array}$ & $\begin{array}{l}\text { Treg cells with a low expression of CD127 provide a more potent } \\
\text { therapy to conventional Treg cells }\end{array}$ \\
\hline $\begin{array}{l}\text { Cao et al., } \\
2009[24]\end{array}$ & NOD/SCID mice & human PBL & $\begin{array}{c}\text { ex vivo expanded } \\
\text { CD4+CD25+ } \\
\text { Tregs }\end{array}$ & $\begin{array}{l}\text { co-transfer of Tregs with human PBL significantly enhanced survival, } \\
\text { reduced GVHD symptoms, and inhibited human IgG/IgM production }\end{array}$ \\
\hline $\begin{array}{l}\text { Tsang et al., } \\
2009[25]\end{array}$ & C57BL/6 mice & $\begin{array}{l}\text { heart } \\
\text { allograft }\end{array}$ & $\begin{array}{l}\mathrm{CD} 4^{+} \mathrm{CD} 25^{+} \\
\text {regulatory } \mathrm{T} \text { cells }\end{array}$ & $\begin{array}{l}\text { Tregs can induce indefinite survival of BALB/c hearts } \\
\text { transplanted into BL/6 recipients when combined with short-term } \\
\text { immunosuppression }\end{array}$ \\
\hline $\begin{array}{c}\text { Kitazawa } \\
\text { et al., } 2008 \\
{[26]}\end{array}$ & $\begin{array}{c}\text { Lewis }\left(\mathrm{RT}-1^{\mathrm{l}}\right) \\
\text { and DA } \\
\left(\mathrm{RT}-1^{\mathrm{a}}\right) \text { rat }\end{array}$ & $\begin{array}{l}\text { cardiac } \\
\text { transplan- } \\
\text { tation }\end{array}$ & $\begin{array}{l}\text { in vitro expanded } \\
\text { nTreg in the } \\
\text { presence of } \\
\text { supCD } 28 \mathrm{MAb}\end{array}$ & $\begin{array}{l}\text { significant prolongation of full } \\
\text { MHC-mismatch cardiac graft survival }\end{array}$ \\
\hline $\begin{array}{l}\text { Feng et al., } \\
2008[27]\end{array}$ & NOD/scid & $\begin{array}{c}\text { skin } \\
\text { and islet } \\
\text { allografts }\end{array}$ & CD25+CD4+ Treg & $\begin{array}{l}\text { prevent rejection of both skin and islet allografts mediated by effector } \\
\text { T cells }\end{array}$ \\
\hline $\begin{array}{l}\text { Veronese } \\
\text { et al., } 2007 \\
{[28]}\end{array}$ & $\begin{array}{l}\text { NOD-scid } \\
\text { IL2rynull mice }\end{array}$ & $\begin{array}{l}\text { islet } \\
\text { allograft }\end{array}$ & $\begin{array}{l}\text { ex vivo } \\
\text { expanded human } \\
\text { CD25+CD4+ Treg }\end{array}$ & $\begin{array}{l}\text { human islet's survival was significantly prolonged following adoptive } \\
\text { transfer of Tregs }\end{array}$ \\
\hline
\end{tabular}

2002, a research revealed that the injection of allogeneic MSCs prolonged skin graft survival in an animal model [40]. Many studies have been conducted on the immunomodulatory properties of MSC since then. Some studies have focused on the tolerance induced by MSCs against immune rejection and graft-versus-host disease (GVHD) [41]. Another study discusses the functions of MSCs on the $\mathrm{T}$ cells infiltrating the central nervous system (CNS) [42]. Thus, it was reported that the injection of MSCs in the experimental autoimmune encephalomyelitis (EAE) mice, may reduce peptide-specific antibodies [43]. In another report, systematic injections of MSCs in the mouse rheumatoid arthritis (RA) model lead to a reduction in inflammatory factors such as IFN- $\gamma$ and activation of T-regulatory cells to reduce inflammation [44]. One more important feature of MSC is engraftment, which makes the migration of these cells into damaged tissues for regenerating or repairing those tissues. This characteristic is a very clinically important feature. In a preclinical model study, wound sites and pro-inflammatory environments 


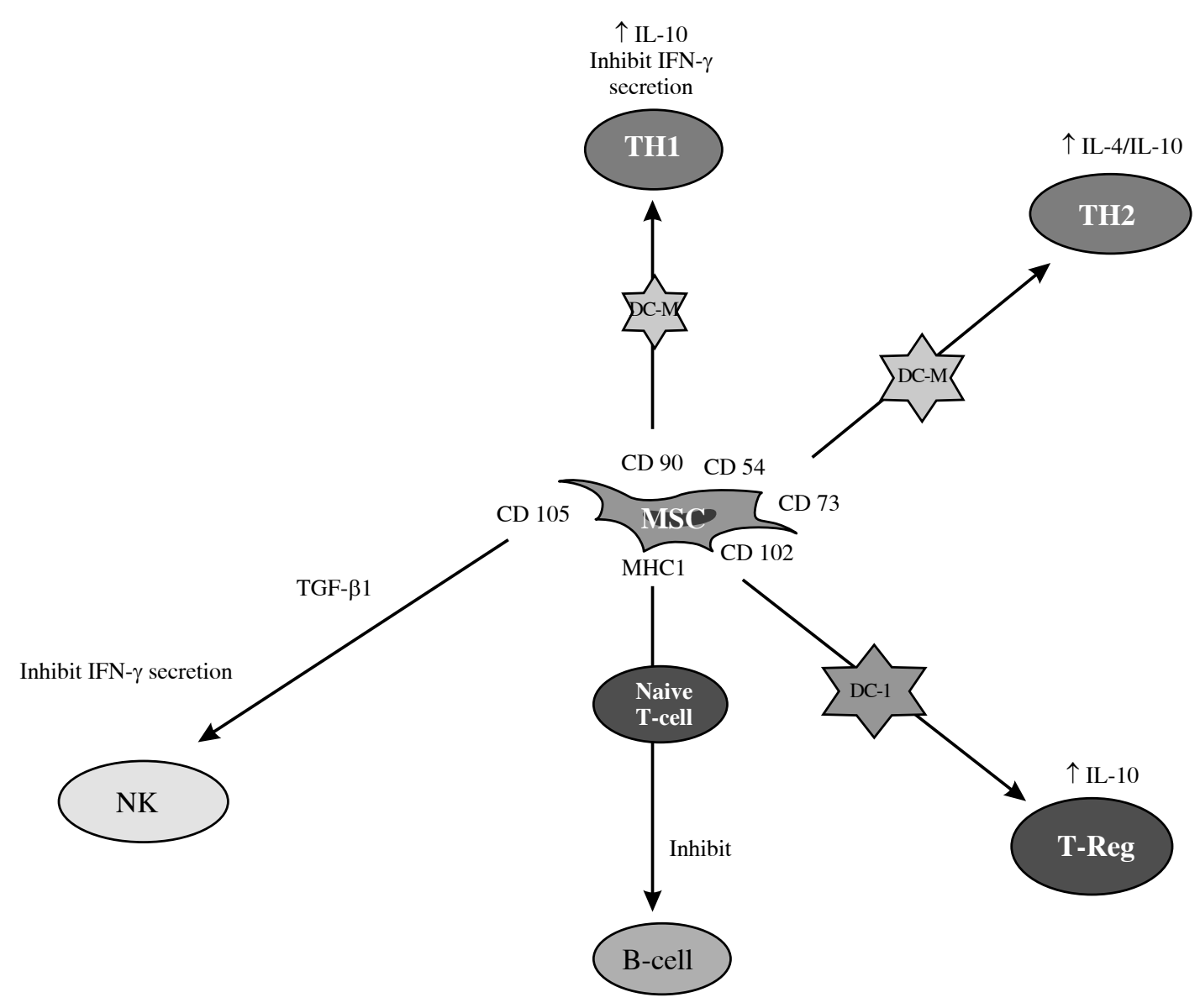

DC-M - dendritic cells-mature, DC-I-dendritic cells-immature, IL - interleukin, T-Reg - T-regulatory cells, NK-natural killer cells, PGE2 - prostaglandin E2, $T G F$ - transforming growth factor

Fig. 1. Immunomodulatory role of mesenchymal stem cells (MSC)

were found capable of enhancing the engraftment of MSCs such as in lung fibrosis in mice induced by bleomycin in mice. However, the majority of MSCs were found in lung following systemic administration in normal recipients, which, disappeared gradually [45]. Recently, it was reported that the MSCs allogenicity does not disturb the stem cells engraftment during the wound healing process, which is an important therapeutic application of these cells. In general, there are two ways of the MSCs delivery: first is the intravenous infusion that leads to MSCs migration to the inflammatory organs [46], and the second one is local injection that causes the accumulation of MSCs in the damaged tissue [47].

In 2007, a phase I clinical trial revealed that peripheral injection of bone marrow-derived MSCs could improve the post-liver transplantation survival [48]. One year later, FDA approved clinical trials for application of MSCs in patients with multiple sclerosis and cartilage defects, which could become potential clinical strategies in the future.

\section{Aerosolized immunosuppression, macrolides and statins}

One of the new approaches is the aerosolized immunosuppressive regimen used specifically for lung transplantation. Many studies reported the use of various aerosolized immunosuppressive regimens and showed their effect in terms of safety, clinical improvement, increasing the graft survival, and prevention of post-transplantation infections (Table 2) [49]. Meanwhile, regimens that include aerosolized corticosteroids have fueled a controversy regarding the use of such therapies in the transplant recipients (Table 2) [50].

Recently, researches have shown that macrolides not only decline the production of pro-inflammatory cytokines such as IL-6 and IL-8 and chemotaxis or apoptosis in activated neutrophils, but also increase anti-inflammatory cytokines, such as IL-10 [62].

It was found that using antibacterial agents against infection and inflammation, such as azithromycin in patients with lung 
Table 2. Available literature considering the use of various aerosolized immunosuppressive and corticosteroid regimens in the transplantation procedure

\begin{tabular}{|c|c|c|c|c|}
\hline Author, year & $\begin{array}{c}\text { Country, } \\
\text { number } \\
\text { of patients }\end{array}$ & Patient & Aerosolized method & Findings \\
\hline \multicolumn{5}{|c|}{ Immunosuppressive regimens } \\
\hline $\begin{array}{c}\text { Lemarie } \text { et al.., } 2011 \\
\text { [51] }\end{array}$ & France, 11 & lung carcinoma & aerosolized gemcitabine & safe, with minimal toxicity \\
\hline Hayes et al., 2010 [52] & USA, 1 & $\begin{array}{l}\text { bronchiolitis obliterans } \\
\text { syndrome (BOS) }\end{array}$ & aerosolized tacrolimus & $\begin{array}{l}\text { clinical improvement in functional } \\
\text { capacity and oxygenation }\end{array}$ \\
\hline Iacono et al., 2006 [53] & USA, 58 & lung-transplant recipients & aerosolized cyclosporine & $\begin{array}{l}\text { improved survival and extended } \\
\text { periods of chronic rejection-free } \\
\text { survival }\end{array}$ \\
\hline Calvo et al., 1999 [54] & Spain, 52 & lung-transplant recipients & aerosolized amphotericin B & $\begin{array}{l}\text { prevented fungal infection in the } \\
\text { postoperative period }\end{array}$ \\
\hline Iacono et al., 1997 [55] & USA, 9 & lung-transplant recipients & aerosolized cyclosporine & reversal of acute lung rejection \\
\hline Keenan et al., 1997 [56] & USA, 18 & lung-transplant recipients & aerosolized cyclosporine & $\begin{array}{l}\text { treatment of refractory acute } \\
\text { allograft rejection }\end{array}$ \\
\hline Nathan et al., 1994 [57] & USA, 9 & lung-transplant recipients & aerosolized pentamidine & $\begin{array}{l}\text { safe and effective form of } \\
\text { pneumocystis carinii pneumonia } \\
\text { (PCP) prophylaxis }\end{array}$ \\
\hline
\end{tabular}

\begin{tabular}{|c|c|c|c|c|}
\hline \multicolumn{5}{|c|}{ Corticosteroid regimens } \\
\hline $\begin{array}{c}\text { Bashoura et al., } 2008 \\
\text { [58] }\end{array}$ & USA, 17 & $\begin{array}{l}\text { constrictive bronchiolitis } \\
\text { in hematopoietic stem cell } \\
\text { transplantation (HSCT) }\end{array}$ & $\begin{array}{l}\text { aerosolized fluticasone } \\
\text { propionate }\end{array}$ & $\begin{array}{l}\text { high-dose inhaled corticosteroids } \\
\text { may be effective }\end{array}$ \\
\hline Naef et al., 2007 [59] & Switzerland, 20 & lung-transplant recipients & $\begin{array}{l}\text { aerosolized fluticasone } \\
\text { propionate }\end{array}$ & $\begin{array}{l}\text { itraconazole co-medication } \\
\text { substantially increases systemic } \\
\text { levels of inhaled fluticasone }\end{array}$ \\
\hline $\begin{array}{l}\text { Whitford et al., } 2002 \\
\text { 50] }\end{array}$ & Australia, 30 & lung-transplant recipients & $\begin{array}{l}\text { aerosolized fluticasone } \\
\text { propionate }\end{array}$ & $\begin{array}{l}\text { ineffective for the prevention } \\
\text { of BOS }\end{array}$ \\
\hline $\begin{array}{c}\text { De Soyza et al., } 2001 \\
{[60]}\end{array}$ & UK, 120 & $\begin{array}{l}\text { lymphocytic bronchiolitis } \\
\text { following lung } \\
\text { transplantation }\end{array}$ & aerosolized budesonide & $\begin{array}{l}\text { a useful addition to systemic } \\
\text { immunosuppressants in } \\
\text { controlling airway inflammation } \\
\text { posttransplant }\end{array}$ \\
\hline $\begin{array}{l}\text { Whitford et al., } 2000 \\
\text { [61] }\end{array}$ & Australia, 30 & lung-transplant recipients & $\begin{array}{l}\text { aerosolized fluticasone } \\
\text { propionate }\end{array}$ & $\begin{array}{l}\text { lung function was not altered over } \\
\text { the } 3 \text { months of treatment }\end{array}$ \\
\hline
\end{tabular}

transplants significantly improved respiratory function and their survival [63]. Another study showed that azithromycin reduced the mortality rate in liver-transplant recipients [64]. These findings motivate some transplant centers to use these therapies in the early post-transplant period. But the long-term use of macrolides can cause antimicrobial resistance [65].

Studies have reported that statin, a cholesterol synthesis inhibitor in the body, may act as an anti-inflammatory agent through inhibiting 3-hydroxy-3-methylglutaryl-coaenzyme A. The first research on the use of statins in transplantation was done on heart-transplant recipients [66]. The reduction of MHCII expression in the endothelial cells and macrophages following the use of statins has also been reported. Thus, this group of drugs may play a crucial role in the onset of the inflammatory process [67]. Another study showed that statins enhance the proliferation of Tregs and inhibit the expression of pro-inflammatory cytokines $[68,69]$. Besides, decreasing cholesterol levels in heart-transplant recipients reduce the organ rejection rate. However, other studies showed that statin is an ineffective therapy in preventing rejection in kidney transplantation, thus the effects of statins in transplantation may prove to be organ specific [70].

\section{Extracorporeal photopheresis}

One of the developed procedures to deal with two more important consequences of hematopoietic stem cells 
transplantation, including GVHD and graft rejection, is the extracorporeal photopheresis (ECP) method. This method decreases the number of T-cells in lymphoma via three mechanisms containing, leukopheresis, incubation of mononuclear cells with $8 \mathrm{MOP}$, and photo-activation of incubated cells with UVA radiation [71].

These cells are then returned to the body and undergo apoptosis [72], increase the T-regulatory levels and anti-inflammatory factors [73]. In a study conducted on lung-transplant recipients receiving either immunosuppressive or ECP treatments, the ECP group was significantly associated with a reduction in the rate of decline in lung function [74]. Although this approach seems to help in improving graft outcome, important questions regarding the use of ECP in the clinical setting, such as length of therapy, concomitant use of immunosuppressive therapy, and cost effectiveness continue to remain unanswered [75]. However, each 6-month ECP therapy requires 24 treatments performed over 4 hours costing $\$ 7,000$ with no insurance coverage [74].

\section{Exosomes and phagosomes}

Formerly, it was reported that presentation of donor MHC antigen before transplantation, could induce immune tolerance in the transplant recipient [76]. Exosomes are antigen-presenting vesicles 50-100 nm in diameter, which can be easily isolated by ultra-centrifugation. Exosomes are generated by a variety of cells, including enterocytes, mast cells, DCs, T and B lymphocytes and tumor cells [77, 78].

Though DCs and tumor cell-derived exosomes such as leukemia cell-derived exosomes (LEXs) have been used to develop antitumor vaccines, their biological properties and antitumor effects are not well described [79]. Thymocyte-derived exosomes reported to have the ability to induce T-regulatory and immune suppression [80, 81]. In a study on the animal model of heart transplantation, exosomes induced a significant prolongation of allograft survival, and long-term graft survival in some recipients [76]. Other researchers showed that mature DCs-derived exosomes can activate the response of T cells and may cause skin graft rejection. Hence immature DC-derived exosomes significantly prolong allograft survival in the heart-transplant recipients [82, 83].

Recently, alloantigen using phagosomes, a vesicle formed around a particle absorbed by phagocytosis, has been developed. The PLGA (polylactic-co-glycolic acid)-containing phagosomes, a nanoparticle sequestering into the phagosome, showed a biochemical composition similar to the original phagocytic plasma membrane. When these phagosomes are exposed to immature DCs of another strain, DCs express low levels of MHC class II and CD86 maturation markers, secrete low levels of the activating cytokines IL-2 and IL-12, and increase IL-10 secretion [84]. In a study, it was reported that phagosome-based alloim- munization reduces cellular immune response and antibody levels significantly [85]. Such findings may encourage the researchers to use PLGA-phagocytosis as a convenient tool in the tolerogenic context of alloantigen administration.

\section{Apoptotic cells}

The potent anti-inflammatory and immunoregulatory effects of apoptotic cells on the antigen presenting cells have been recently reported $[86,87]$. Broad spectrums of factors are likely help to determine the tolerogenic or immunogenic role of DCs next to uptake of apoptotic cells. Early stage apoptotic cells are more likely known to induce tolerance than late stage ones $[88,89]$. A number of molecules on the surface of apoptotic cells interact with other cellular receptors and released cytokines [90]. Besides, DCs maturation status can play a role in the induction of tolerogenicity or immunogenicity.

Several studies have shown that an increase in the surface marker of the immature DCs, including MHCII, CD40, CD80, CD83, CD86, even if these cells are exposed to LPS and TNF- $\alpha$, does not happen in case of the exposure of these cells to apoptotic cells [91, 92]. Also, if early stage DCs are exposed to apoptotic cells, the expression and secretion of inflammatory cytokines, including IL- $1 \alpha$, IL-1 $\beta$, IL-6 and tumor necrosis factor $\alpha$ (TNF- $\alpha$ ), decreases, while the expression of anti-inflammatory factors such as TGF and IL-10 increases [93, 94]. Apoptotic cells that carry donor $\mathrm{MHC}$ molecules has been used in many animal models to prevent adverse reaction following transplantation, showed favorable results [95-97].

Apoptotic cells usage has many advantages, include transferring a strong signal of immunosuppression to DCs [91], are a rich source of MHC molecules [92], are easy to prepare and with relatively safe intravenous injections [98]. Following the intravascular injection, apoptotic cells are efficiently captured by splenic DCs [99], which present the apoptotic cell derived antigens to T cells [100].

Post-cardiac transplantation intravenous injection of apoptotic cells in a mouse model led to reduction in B and $\mathrm{T}$ cell responses against the donor antigens, blocking of CD40-CD154 and prolonged allograft survival [101].

\section{Immunoisolation}

Immunoisolation is a new proposed method that aims to isolate and hide nonself (the graft cell) antigens from the host's immune system. In 1980, Lim and Sun showed that transplantation of the encapsulated-islets can recover in diabetic eugelycemia in rats [102]. Immunosuppression-free transplantation needs a protective cover that does not interfere with the cells viability and function, and keeps them out of reach of the immune system to avoid transplant rejection. Biomaterials used to encapsulate the transplant cells should be biocompatible and allow for penetrating 
nutrients, hormones and oxygen into the cells. The most commonly applied biomaterials are alginate [102], chitosan [103], agarose [104] and polyethylene glycol [105]. However, these biomaterials allow T cells, macrophages and cytokines such as IL- $1 \beta$, TNF- $\alpha$ and IFN- $\gamma$ to easily penetrate into the capsules and damage and destroy the encapsulated islets. Thus, a polyamino acid layer, which is coated by alginate, can be used for this purpose.

The positive and negative charges of poly-amino acid and alginate react to form a complex.

Two major amino acid polymers are PLL (Poly L-Lysine) and PLO (Poly L-Ornithine), which PLL is the most popular one. Poly L-Ornithine has some advantages compared to the PLL, including better performance in preventing the infiltration of immune cells into the capsule. Hence, PLO has more resistance against mechanical stresses, such as changes in osmotic pressure.

Immuno-blocking is a cutting-edge technology, in which the inner surface of blood vessels is coated with a nano-barrier membrane (NB-LVF4) to hide the endothelial antigens from the immunological system. NB-LVF4 is injected through the arterial line of the graft immediately prior to transplantation to cover its inner surface. This nano-barrier membrane allows the passage of nutrients and oxygen [106, 107].

In a study on a canine model of renal allograft using a bioengineered interface consisting of a NB-LVF4 was associated with a reduction in the stimulation index up to $99.98 \%$, and prolonged allograft survival has been achieved in the absence of systemic immunosuppression [106]. In another study using NB-LVF4 as a targeted drug delivery system, allograft rejection occurred in controls by 7 days, while the group treated with NB-LVF4 showed mean onset of rejection on day 30 . Thus, they claimed that treatment with the NB-LVF4 membrane delays the onset of allograft rejection in the absence of systemic immunosuppression [108]. However, one of the major limitations of this approach is the need to use tolerogenic regimen besides the use of NB-LVF4; besides, this method does not have immunosuppression properties and only provides a 30-day window to use the immunosuppression regimen.

\section{Summary}

Immunosuppressive therapy has contributed significantly to improved survival after solid organ transplantation. Nevertheless, treatment-related adverse events and persistently a high risk of chronic graft rejection remain as major obstacles to long-term survival after transplantation. Improvements in procedures to monitor immunosuppression, the development of new agents, and better understanding of transplant immunobiology are essential for further improvements in outcome.
The authors declare no conflict of interest.

\section{References}

1. Cools N, Ponsaerts P, Van Tendeloo VF, Berneman ZN (2007): Balancing between immunity and tolerance: an interplay between dendritic cells, regulatory $\mathrm{T}$ cells, and effector T cells. J Leukoc Biol 82: 1365-1374.

2. Steinman RM, Banchereau J (2007): Taking dendritic cells into medicine. Nature 449: 419-426.

3. Merad M, Sathe P, Helft J, et al. (2013): The dendritic cell lineage: ontogeny and function of dendritic cells and their subsets in the steady state and the inflamed setting. Annu Rev Immunol 31: 563-604.

4. Cisse B, Caton ML, Lehner M, et al. (2008): Transcription factor E2-2 is an essential and specific regulator of plasmacytoid dendritic cell development. Cell 135: 37-48.

5. Mahnke K, Schmitt E, Bonifaz L, et al. (2002): Immature, but not inactive: the tolerogenic function of immature dendritic cells. Immunol Cell Biol 80: 477-483.

6. Salomon B, Lenschow DJ, Rhee L, et al. (2000): B7/ CD28 costimulation is essential for the homeostasis of the CD4+CD25+ immunoregulatory T cells that control autoimmune diabetes. Immunity 12: 431-440.

7. Hilkens CM, Isaacs JD, Thomson AW (2010): Development of dendritic cell-based immunotherapy for autoimmunity. Int Rev Immunol 29: 156-183.

8. Ali A, Garrovillo M, Jin MX, et al. (2000): Major histocompatibility complex class I peptide-pulsed host dendritic cells induce antigen-specific acquired thymic tolerance to islet cells 1, 2. Transplantation 69: 221-226.

9. Garrovillo M, Ali A, Oluwole SF (1999) Indirect Allorecognition in Acquired Thymic Tolerance: Induction of Donor-Specific Tolerance to Rat Cardiac Allografts By Allopeptide-Pulsed Host Dendritic Cells 1, 2. Transplantation 68:1827-1834

10. Taner T, Hackstein H, Wang Z, et al. (2005): Rapamycin-treated, alloantigen-pulsed host dendritic cells induce Ag-specific T cell regulation and prolong graft survival. Am J Transplant 5: 228-236.

11. Fu F, Li Y, Qian S, et al. (1996): Costimulatory molecule-deficient dendritic cell progenitors (MHC class II+, CD80dim, CD86-) prolong cardiac allograft survival in nonimmunosuppressed recipients. Transplantation 62: 659-665.

12. Rastellini C, Lu L, Ricordi C, et al. (1995): Granulocyte/macrophage colony-stimulating factor-stimulated hepatic dendritic cell progenitors prolong pancreatic islet allograft survival. Transplantation 60: 1366-1370.

13. Björck P, Coates PT, Wang Z, et al. (2005): Promotion of long-term heart allograft survival by combination of mobilized donor plasmacytoid dendritic cells and anti-CD154 monoclonal antibody. J Heart Lung Transplant 24: 11181120.

14. Yu G, Xu X, Vu MD, et al. (2006): NK cells promote transplant tolerance by killing donor antigen-presenting cells. J Exp Med 203: 1851-1858.

15. Morelli AE, Thomson AW (2007): Tolerogenic dendritic cells and the quest for transplant tolerance. Nat Rev Immunol 7: 610-621.

16. Sagoo P, Ali N, Garg G, et al. (2011): Human regulatory $\mathrm{T}$ cells with alloantigen specificity are more potent inhibitors 
of alloimmune skin graft damage than polyclonal regulatory T cells. Sci Transl Med 3: 83ra42-83ra42.

17. Wu DC, Hester J, Nadig SN, et al. (2013): Ex vivo expanded human regulatory $\mathrm{T}$ cells can prolong survival of a human islet allograft in a humanized mouse model. Transplantation 96: 707-716.

18. Issa F, Hester J, Goto R, et al. (2010): Ex vivo-expanded human regulatory $\mathrm{T}$ cells prevent the rejection of skin allografts in a humanised mouse model. Transplantation 90: 1321-1327.

19. Takasato F, Morita R, Schichita T, et al. (2014): Prevention of allogeneic cardiac graft rejection by transfer of ex vivo expanded antigen-specific regulatory T-cells. PLoS One 9: e87722.

20. Wolf D, Schreiber TH, Tryphonopoulos P, et al. (2012): Tregs expanded in vivo by TNFRSF25 agonists promote cardiac allograft survival. Transplantation 94: 569-574.

21. Guo X, Jie Y, Ren D, et al. (2012): In vitro-expanded CD4+CD25highFoxp3+ regulatory T cells controls corneal allograft rejection. Hum Immunol 73: 1061-1067.

22. Yi S, Ji M, Wu J (2012): Adoptive transfer with in vitro expanded human regulatory $\mathrm{T}$ cells protects against porcine islet xenograft rejection via interleukin-10 in humanized mice. Diabetes 61: 1180-1191.

23. Nadig SN, Wieckiewicz J, Wu DC, et al. (2010): In vivo prevention of transplant arteriosclerosis by ex vivo-expanded human regulatory T cells. Nat Med 16: 809-813.

24. Cao T, Soto A, Zhou W, et al. (2009): Ex vivo expanded human $\mathrm{CD} 4+\mathrm{CD} 25+\mathrm{Foxp} 3+$ regulatory $\mathrm{T}$ cells prevent lethal xenogenic graft versus host disease (GVHD). Cell Immunol 258: 65-71.

25. Tsang JY, Tanriver Y, Jiang S, et al. (2009): Indefinite mouse heart allograft survival in recipient treated with CD4+CD25+ regulatory $\mathrm{T}$ cells with indirect allospecificity and short term immunosuppression. Transpl Immunol 21: 203-209.

26. Kitazawa Y, Fujino M, Sakai T, et al. (2008): Foxp3-expressing regulatory $\mathrm{T}$ cells expanded with $\mathrm{CD} 28$ superagonist antibody can prevent rat cardiac allograft rejection. J Heart Lung Transplant 27: 362-371.

27. Feng G, Wood KJ, Bushell A (2008): Interferon- $\gamma$ conditioning ex vivo generates $\mathrm{CD} 25+\mathrm{CD} 62 \mathrm{~L}+\mathrm{Foxp} 3+$ regulatory $\mathrm{T}$ cells that prevent allograft rejection: potential avenues for cellular therapy. Transplantation 86: 578-589.

28. Veronese F, Rotman S, Smith RN, et al. (2007): Pathological and clinical correlates of FOXP3+ cells in renal allografts during acute rejection. Am J Transplant 7: 914-922.

29. Bianco P, Robey PG, Simmons PJ (2008): Mesenchymal stem cells: revisiting history, concepts, and assays. Cell Stem Cell 2: 313-319.

30. Pittenger MF, Mackay AM, Beck SC (1999): Multilineage potential of adult human mesenchymal stem cells. Science 284: 143-147.

31. Augello A, Tasso R, Negrini SM (2005): Bone marrow mesenchymal progenitor cells inhibit lymphocyte proliferation by activation of the programmed death 1 pathway. Eur J Immunol 35: 1482-1490.

32. Chabannes D, Hill M, Merieau E (2007): A role for heme oxygenase-1 in the immunosuppressive effect of adult rat and human mesenchymal stem cells. Blood 110: 3691-3694.

33. Ebrahimi A, Lalvand N (2013): Drug delivery using genetically modified mesenchymal stem cells: a promising targeted-delivery method. J Drugs Med.
34. Jones BJ, Brooke G, Atkinson K, McTaggart SJ. (2007): Immunosuppression by placental indoleamine 2,3-dioxygenase: a role for mesenchymal stem cells. Placenta 28: 1174-1181.

35. Corcione A, Benvenuto F, Ferretti E, et al. (2006): Human mesenchymal stem cells modulate B-cell functions. Blood 107: 367-372.

36. Choi YS, Jeong JA, Lim DS (2012): Mesenchymal stem cell-mediated immature dendritic cells induce regulatory $\mathrm{T}$ cell-based immunosuppressive effect. Immunol Invest 41: 214-229.

37. Cohen PA, Ko JS, Storkus WJ, et al. (2012): Myeloid-derived suppressor cells adhere to physiologic STAT3-vs STAT5-dependent hematopoietic programming, establishing diverse tumor-mediated mechanisms of immunologic escape. Immunol Invest 41: 680-710.

38. Monu NR, Frey AB (2012): Myeloid-derived suppressor cells and anti-tumor T cells: a complex relationship. Immunol Invest 41: 595-613.

39. Zhang W, Ge W, Li C, et al. (2004): Effects of mesenchymal stem cells on differentiation, maturation, and function of human monocyte-derived dendritic cells. Stem Cells Dev 13: 263-271.

40. Bartholomew A, Sturgeon C, Siatskas M, et al. (2002): Mesenchymal stem cells suppress lymphocyte proliferation in vitro and prolong skin graft survival in vivo. Exp Hematol 30: $42-48$.

41. Le Blanc K, Rasmusson I, Sundberg B, et al. (2004): Treatment of severe acute graft-versus-host disease with third party haploidentical mesenchymal stem cells. Lancet 363 : 1439-1441.

42. Zappia E, Casazza S, Pedemonte E, et al. (2005): Mesenchymal stem cells ameliorate experimental autoimmune encephalomyelitis inducing T-cell anergy. Blood 106: 1755-1761.

43. Gerdoni E, Gallo B, Casazza S, et al. (2007): Mesenchymal stem cells effectively modulate pathogenic immune response in experimental autoimmune encephalomyelitis. Ann Neurol 61: 219-227.

44. Chen FH, Tuan RS (2008): Mesenchymal stem cells in arthritic diseases. Arthritis Res Ther 10: 223.

45. Ortiz LA, Gambelli F, McBride C, et al. (2003): Mesenchymal stem cell engraftment in lung is enhanced in response to bleomycin exposure and ameliorates its fibrotic effects. Proc Natl Acad Sci U S A 100: 8407-8411.

46. Sakaida I, Terai S, Yamamoto N, et al. (2004): Transplantation of bone marrow cells reduces $\mathrm{CCl} 4$-induced liver fibrosis in mice. Hepatology 40: 1304-1311.

47. Chen CP, Liu SH, Huang JP, et al. (2009): Engraftment potential of human placenta-derived mesenchymal stem cells after in utero transplantation in rats. Hum Reprod 24: 154-165.

48. Mohamadnejad M, Alimoghaddam K, Mohyeddin-Bonab M, et al. (2007): Phase 1 trial of autologous bone marrow mesenchymal stem cell transplantation in patients with decompensated liver cirrhosis. Arch Iran Med 10: 459-466.

49. Iacono AT, Johnson BA, Grgurich WF, et al. (2006): A randomized trial of inhaled cyclosporine in lung-transplant recipients. N Engl J Med 354: 141-150.

50. Whitford H, Walters EH, Levvey B, et al. (2002): Addition of inhaled corticosteroids to systemic immunosuppression after lung transplantation: a double-blind, placebo-controlled trial. Transplantation 73: 1793-1799.

51. Lemarie E, Vecellio L, Hureaux J, et al. (2011): Aerosolized gemcitabine in patients with carcinoma of the lung: feasi- 
bility and safety study. J Aerosol Med Pulm Drug Deliv 24: 261-270.

52. Hayes D, Zwischenberger J, Mansour H (2010): Aerosolized tacrolimus: a case report in a lung transplant recipient. In: Transplantation proceedings. Elsevier, Philadelphia: 38763879.

53. Iacono AT, Johnson BA, Grgurich WF, et al. (2006): A randomized trial of inhaled cyclosporine in lung-transplant recipients. N Engl J Med 354: 141-150.

54. Calvo V, Borro JM, Morales P, et al. (1999): Antifungal prophylaxis during the early postoperative period of lung transplantation. Chest 115: 1301-1304.

55. Iacono AT, Smaldone GC, Keenan RJ, et al. (1997): Dose-related reversal of acute lung rejection by aerosolized cyclosporine. Am J Respir Crit Care Med 155: 1690-1698.

56. Keenan RJ, Iacono A, Dauber JH, et al. (1997): Treatment of refractory acute allograft rejection with aerosolized cyclosporine in lung transplant recipients. J Thorac Cardiovasc Surg 113: 335-341.

57. Nathan SD, Ross D, Zakowski P, et al. (1994): Utility of inhaled pentamidine prophylaxis in lung transplant recipients. Chest 105: 417-420.

58. Bashoura L, Gupta S, Jain A, et al. (2008): Inhaled corticosteroids stabilize constrictive bronchiolitis after hematopoietic stem cell transplantation. Bone Marrow Transplant 41: 63-67.

59. Naef R, Schmid C, Hofer M, et al. (2007): Itraconazole comedication increases systemic levels of inhaled fluticasone in lung transplant recipients. Respiration 74: 418-422.

60. De Soyza A, Fisher AJ, Small T, Corris PA (2001): Inhaled corticosteroids and the treatment of lymphocytic bronchiolitis following lung transplantation. Am J Respir Crit Care Med 164: 1209-1212.

61. Whitford H, Orsida B, Kotsimbos T, et al. (1999): Bronchoalveolar lavage cellular profiles in lung transplantation: the effect of inhaled corticosteroids. Ann Transplant 5: 31-37.

62. Kanoh S, Rubin BK (2010): Mechanisms of action and clinical application of macrolides as immunomodulatory medications. Clin Microbiol Rev 23: 590-615.

63. Gerhardt SG, McDyer JF, Girgis RE, et al. (2003): Maintenance azithromycin therapy for bronchiolitis obliterans syndrome: results of a pilot study. Am J Respir Crit Care Med 168: 121-125.

64. Verleden GM, Vanaudenaerde BM, Dupont LJ, Van Raemdonck DE (2006): Azithromycin reduces airway neutrophilia and interleukin- 8 in patients with bronchiolitis obliterans syndrome. Am J Respir Crit Care Med 174: 566-570.

65. Crosbie PA, Woodhead MA (2009): Long-term macrolide therapy in chronic inflammatory airway diseases. Eur Respir J 33: 171-181.

66. Kobashigawa JA, Katznelson S, Laks H, et al. (1995): Effect of pravastatin on outcomes after cardiac transplantation. N Engl J Med 333: 621-627.

67. Kwak B, Mulhaupt F, Myit S, Mach F (2000): Statins as a newly recognized type of immunomodulator. Nat Med 6: 1399-1402.

68. Broady R, Levings MK (2008): Graft-versus-host disease: suppression by statins. Nat Med 14: 1155-1156.

69. Steffens S, Mach F (2006): Drug insight: immunomodulatory effects of statins - potential benefits for renal patients? Nat Clin Pract Nephrol 2: 378-387.

70. Palmer SC, Craig JC, Navaneethan SD, et al. (2012): Benefits and harms of statin therapy for persons with chronic kidney disease: a systematic review and meta-analysis. Ann Intern Med 157: 263-275.

71. Edelson R, Berger C, Gasparro F, et al. (1987): Treatment of cutaneous T-cell lymphoma by extracorporeal photochemotherapy. N Engl J Med 316: 297-303.

72. Knobler R, Barr ML, Couriel DR, et al. (2009): Extracorporeal photopheresis: past, present, and future. J Am Acad Dermatol 61: 652-665.

73. Gatza E, Rogers CE, Clouthier SG, et al. (2008): Extracorporeal photopheresis reverses experimental graft-versus-host disease through regulatory T cells. Blood 112: 1515-1521.

74. Morrell MR, Despotis GJ, Lublin DM, et al. (2010): The efficacy of photopheresis for bronchiolitis obliterans syndrome after lung transplantation. J Heart Lung Transplant 29: 424-431.

75. Chiesa-Fuxench ZC, González-Chávez J (2010): Extracorporeal photopheresis: a review on the immunological aspects and clinical applications. P R Health Sci J 29: 337-347.

76. Pęche H, Heslan M, Usal C, et al (2003): Presentation of donor major histocompatibility complex antigens by bone marrow dendritic cell-derived exosomes modulates allograft rejection. Transplantation 76: 1503-1510.

77. Kim SH, Lechman ER, Bianco N, et al. (2005): Exosomes derived from IL-10-treated dendritic cells can suppress inflammation and collagen-induced arthritis. J Immunol 174: 6440-6448.

78. Singh PP, LeMaire C, Tan JC, et al. (2011): Exosomes released from M. tuberculosis infected cells can suppress IFN- $\gamma$ mediated activation of naïve macrophages. PLoS One 6: e18564.

79. Yao Y, Wang C, Wei W, et al. (2014): Dendritic cells pulsed with leukemia cell-derived exosomes more efficiently induce antileukemic immunities. PLoS One 9: e91463.

80. Théry C, Duban L, Segura E, et al. (2002): Indirect activation of nadve CD4+ T cells by dendritic cell-derived exosomes. Nat Immunol 3: 1156-1162.

81. Vincent-Schneider H, Stumptner-Cuvelette P, Lankar D, et al. (2002): Exosomes bearing HLA-DR1 molecules need dendritic cells to efficiently stimulate specific T cells. Int Immunol 14: 713-722.

82. Peche H, Renaudin K, Beriou G, et al. (2006): Induction of tolerance by exosomes and short-term immunosuppression in a fully MHC-mismatched rat cardiac allograft model. Am J Transplant 6: 1541-1550.

83. Segura E, Nicco C, Lombard B, et al. (2005): ICAM-1 on exosomes from mature dendritic cells is critical for efficient naive T-cell priming. Blood 106: 216-223.

84. Ureta G, Osorio F, Morales J, et al. Generation of dendritic cells with regulatory properties. Elsevier, Philadelphia: 633637.

85. Desjardins M, Huber LA, Parton RG, Griffiths G (1994): Biogenesis of phagolysosomes proceeds through a sequential series of interactions with the endocytic apparatus. J Cell Biol 124: 677-688.

86. Morelli AE, Larregina AT (2010): Apoptotic cell-based therapies against transplant rejection: role of recipient's dendritic cells. Apoptosis 15: 1083-1097.

87. Pessach I, Shimoni A, Nagler A (2012): Apoptotic cells in allogeneic hematopoietic stem cell transplantations: "turning trash into gold". Leuk Lymphoma 53: 2130-2135.

88. Chernysheva AD, Kirou KA, Crow MK (2002): T cell proliferation induced by autologous non-T cells is a response to apoptotic cells processed by dendritic cells. J Immunol 169: 1241-1250. 
89. Sauter B, Albert ML, Francisco L, et al. (2000): Consequences of cell death exposure to necrotic tumor cells, but not primary tissue cells or apoptotic cells, induces the maturation of immunostimulatory dendritic cells. J Exp Med 191: 423-434.

90. Skoberne M, Somersan S, Almodovar W, et al. (2006): The apoptotic-cell receptor CR3, but not $\alpha v \beta 5$, is a regulator of human dendritic-cell immunostimulatory function. Blood 108: 947-955.

91. Gleisner MA, Rosemblatt M, Fierro JA, Bono MR. Delivery of alloantigens via apoptotic cells generates dendritic cells with an immature tolerogenic phenotype. Elsevier, Philadelphia: 2325-2333.

92. Stuart LM, Lucas M, Simpson C, et al. (2002): Inhibitory effects of apoptotic cell ingestion upon endotoxin-driven myeloid dendritic cell maturation. J Immunol 168: 1627 1635.

93. Inaba K, Turley S, Yamaide F, et al. (1998): Efficient presentation of phagocytosed cellular fragments on the major histocompatibility complex class II products of dendritic cells. Exp Med 188: 2163-2173.

94. Williams CA, Harry RA, McLeod JD (2008): Apoptotic cells induce dendritic cell-mediated suppression via interferon-gamma-induced IDO. Immunology 124: 89-101.

95. de Carvalho Bittencourt M, Perruche S, Contassot E, et al. (2001): Intravenous injection of apoptotic leukocytes enhances bone marrow engraftment across major histocompatibility barriers. Blood 98: 224-230.

96. Morelli AE, Larregina AT, Shufesky WJ, et al. (2003): Internalization of circulating apoptotic cells by splenic marginal zone dendritic cells: dependence on complement receptors and effect on cytokine production. Blood 101: 611-620.

97. Morelli AE (2006): The immune regulatory effect of apoptotic cells and exosomes on dendritic cells: its impact on transplantation. Am J Transplant 6: 254-261.

98. Iyoda T, Shimoyama S, Liu K, et al. (2002): The CD8+ dendritic cell subset selectively endocytoses dying cells in culture and in vivo. J Exp Med 195: 1289-1302.

99. Nouri-Shirazi M, Guinet E (2002): Direct and indirect cross-tolerance of alloreactive $\mathrm{T}$ cells by dendritic cells retained in the immature stage. Transplantation 74: 10351044

100. Xu DL, Liu Y, Tan JM, et al. (2004) Marked prolongation of murine cardiac allograft survival using recipient immature dendritic cells loaded with donor-derived apoptotic cells. Scand J Immunol 59: 536-544.

101. Wang Z, Larregina AT, Shufesky WJ, et al. (2006): Use of the inhibitory effect of apoptotic cells on dendritic cells for graft survival via T-cell deletion and regulatory T cells. Am J Transplant 6: 1297-1311.

102. Lim F, Sun AM (1980): Microencapsulated islets as bioartificial endocrine pancreas. Science 210: 908-910.

103. Zielinski A, Aebischer P (1994): Chitosan as a matrix for mammalian cell encapsulation. Biomaterials 15: 1049-1056.

104. Iwata H, Amemiya H, Matsuda T, et al. (1989): Evaluation of microencapsulated islets in agarose gel as bioartificial pancreas by studies of hormone secretion in culture and by xenotransplantation. Diabetes 38: 224-225.

105. Cruise GM, Hegre OD, Lamberti FV, et al. (1999): In vitro and in vivo performance of porcine islets encapsulated in interfacially photopolymerized poly (ethylene glycol) diacrylate membranes. Cell Transplant 8: 293-306.
106. Brasile L, Glowacki P, Castracane J, Stubenitsky BM (2010): Pretransplant kidney-specific treatment to eliminate the need for systemic immunosuppression. Transplantation 90: 1294-1298.

107. Stubenitsky BM, Brasile L, Rebellato LM, et al. (2009): Delayed skin allograft rejection following matrix membrane pretreatment. J Plast Reconstr Aesthet Surg 62: 520-525.

108. Brasile L, Glowacki P, Stubenitsky BM (2011): Bioengineered skin allografts: a new method to prevent humoral response. ASAIO J 57: 239-243. 